\title{
Analysing the Effectiveness of the Personality Symbols/Icons
}

\section{Ipek Halim}

\begin{abstract}
Personality symbol can cover all the identifications of the brand. It can be the face or the soul of the company. Their effect on the brand image is huge. The research focuses on calculating the roles and effectives of the personality symbols. It aims to bring in suggestions for developing a successful personality symbols and lists advantages and disadvantages of different types of personality symbols. It does a detailed copy testing. Apart from conducting focus groups to analyse how the target market interprets the personality symbols it also conducts in depth interviews both with the advertising agencies and the targeted audiences.
\end{abstract}

Keywords: Personality Symbol, commercials, effectiveness 


\section{Introduction}

This study focuses on the roles and effectiveness of personality symbols in the TV commercials. It defines what personality symbol is and underlines its possible limitations and advantages. The study also by providing examples of internationally recognized personality symbols and by discussing their characteristics it groups them into different categories such as human, abstract or iconic. Then, it aims to calculate how much each type of personality symbol conveys the brand's messages and allows it to be read successfully as it is 'originally' intended. It also develops suggestion lists for creating a successful personality symbols.

The research is composed of three parts. In the first part scheduled interviews have been carried out with the chosen advertising agencies which had developed personality symbols. In the second part of the research, the audiences with the characteristics allowing them to be the target market of the chosen personality symbols were interviewed. Focus groups have also been conducted to analyse how the target market interprets the personality symbols. In the third and the final part of the research the information obtained from the potential target market and the information received from the related personality symbol creators (advertising agencies) have been compared. The information gathered from this comparison allows us to calculate the effectiveness of each type of personality symbol.

The research in general provides information on whether the TV commercials with personality symbols attract people and if they could be remembered. It also indicates the advantages and the disadvantages of each type of personality symbol in conveying the intended brand messages.

\section{Understanding Personality Symbols}

Personality symbol is a type of advertising execution. It involves developing a central character through which the brand delivers its benefits. It also allows the brand to build an identity, to differentiate itself from the competitors. In other words, personality symbol is creating a symbol/icon that is associated with the product or the brand (Belch and Belch, 1999, p.274).

According to Zeren successful personality symbols are sincere and consistent. They have an identity. They do not lie. Personality symbols project ones needs and wishes. People see what they want to be in the personality symbols. For him, creating a personality symbol is social engineering. It targets the social needs and it is one of the most effective strategies in the field 
of marketing communication. (Zeren A., 2009, Sunday, 27 September 2009 23:47, Reklamlarda İkon Kullanımı (Use of icons in Advertisements), Pazarilla).

Some internationally well -known examples of personality symbols are Tony the Tiger, Energizer Bunny, Mr. Peanut, Johnnie Walker, Betty Crocker, Marlboro Man, Michelin Man, Quaker Oat Man, Charlie the Tuna, the Jolly Green Giant and so on.

Personality symbols can be used for different product types and can aim to reach different target markets. The use of personality symbol goes back to late 1800's. One of the oldest personality symbols created in 1893 is Aunt Jemima, promoting pancake mixes and syrup. The other oldest personality symbol which is still in use just like Aunt Jemima is Michelin Tyre's personality symbol, Michelin Man.

A successfully, well developed personality symbol can provide durability in the messages and therefore build a prestige for the brand. Also by using personality symbols remembering the brand is made easy and its benefits can be conveyed easily. Mostly the creative advertising campaigns that base their communication strategy on personality symbols find the adaption of their messages to other formats and media channels easier as well. (Marra, J.L., 1990, p.25). A personality symbol can take place at the TV commercials; can also be adapted to billboards and magazines. As M\&M does, personality symbols can also be used on the pack and be a sales promotion element as well. KFC uses its personality symbol as plastic salt and pepper shaker, McDonalds turned its personality symbol into a plastic piggy bank. Also Kellogg's personality symbols Tony the Tiger and the Jolly Green Giant have been converted into vinyl squeeze toys (Dotz, 1997, p. 27, 37 ). Personality symbols can get their place in your home and appear on the screen. Since a personality symbol is a character whom can walk, talk, sing, taste food, it becomes convenient to give them a part in any activity that are sponsored by the company as well. A personality symbol can become a friend or a cultural icon.

In other words, personality symbols not only stay as characters that appear in the papers or on the screens but can also be transferred into 'real' life. They can mentally and physically touch their target market. The opportunity to have an easy adaptability of a personality symbol can also help it to stick in the target audiences' minds. 


\section{Types of Personality Symbols}

Although there are some collected information and many references sharing the visual examples of the personality symbols there are not many studies focusing on the types of the personality symbols. This paper covers many different examples of the personality symbols and tried to group them. Although personality symbols should not be limited with the given list grouping them is also useful while aiming to analyse them. The most used personality symbols can be found in five different groups:

\section{Human,}

2. Animal,

3. Magical, mythical or an already known character,

\section{Iconic,}

\section{Illusionary or Abstract.}

Personality symbols can be human. Whereas a human personality symbol can be a 'real, living', celebrity or an ordinary person, he/she can also be a 'created' person. For example "Betty Crocker is a computer generated hybrid of 75 real American faces" (Schultz, D.P, Schultz, S. E., 1998, p. 462). Depending on the message a child, a man or a woman can be selected. There are many human personality symbols from different ethnic backgrounds as well. Some examples for human personality symbols are Aunt Jemima, Oaken Oats Man, Betty Crocker, Blue Nun, Ronald McDonald, Marlboro Man, and Colonel Sanders...

\section{Here are some examples of human personality symbols}

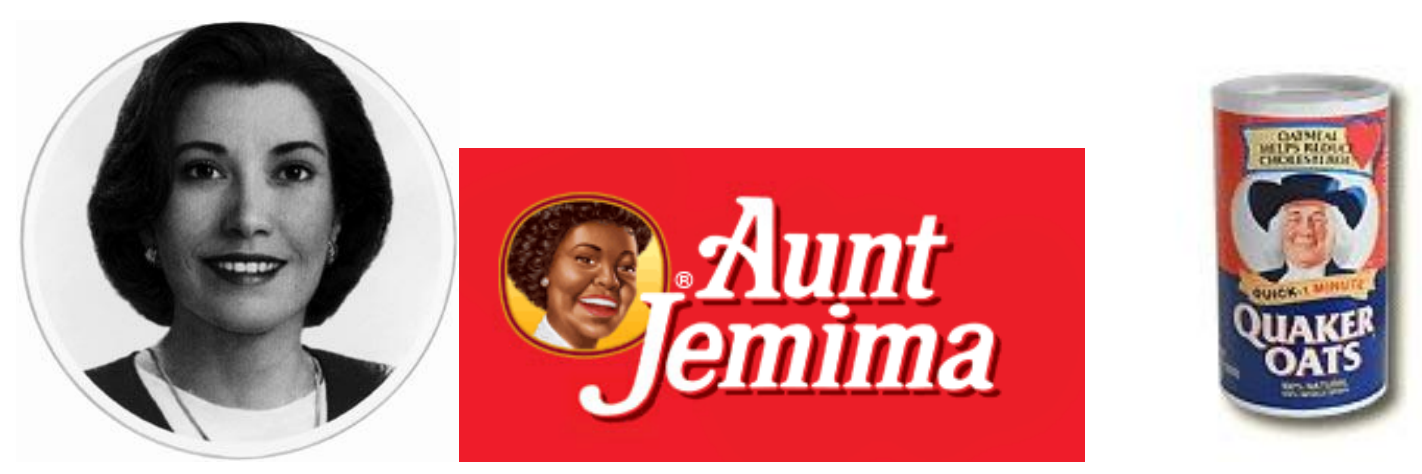


Personality symbols can be animals too. Such as Eveready batteries' Eveready Cat, Borden dairy product's Elsie Cow, Tony the Tiger for the Kellogg Company, sugar frosted flakes, Hamm's Bear for Pabst Brewing Company or Nestle chocolate's Nestle Rabbit. The animal personality symbols can be developed in different techniques. Some are puppets, some are animations or cartoon and some has a 'real' look.

The teddy bear personality symbol of the fabric softener Snuggle is suggested as ".... perfect symbol for a fabric softener that tames the rough texture of clothing" (Belch, G.E. and Belch M.A., 1998, p. 142). Dotz and Morton (1996) stresses the semiotic analyses for the usage of the bears as advertising characters and suggest that to use a real bear or a teddy bear creates significant difference on the perception. Whereas real bear imparts a sense of nature, teddy bears are used for their cute cuddliness (Dotz, W. and Morton J. 1996, p.44).

As Dotz and Morton (1996) also highlight the assistance of the animalism -the historical attributes to animals and the embodiments of various spirits- in selecting an animal personality symbol. For example the reason why Eveready chose a cat is, because "....of the old myth that cats have nine lives" (1996, p 42).

All these explanations give us clues that choosing a correct personality symbol which will deliver the desired message and allow it to be perceived as intended is a complex issue. Not only choosing the type of the personality symbol but choosing which production/execution techniques will be used can also be a very important decision that can affect the whole success of the communication.

\section{Here are some examples of animal personality symbols.}
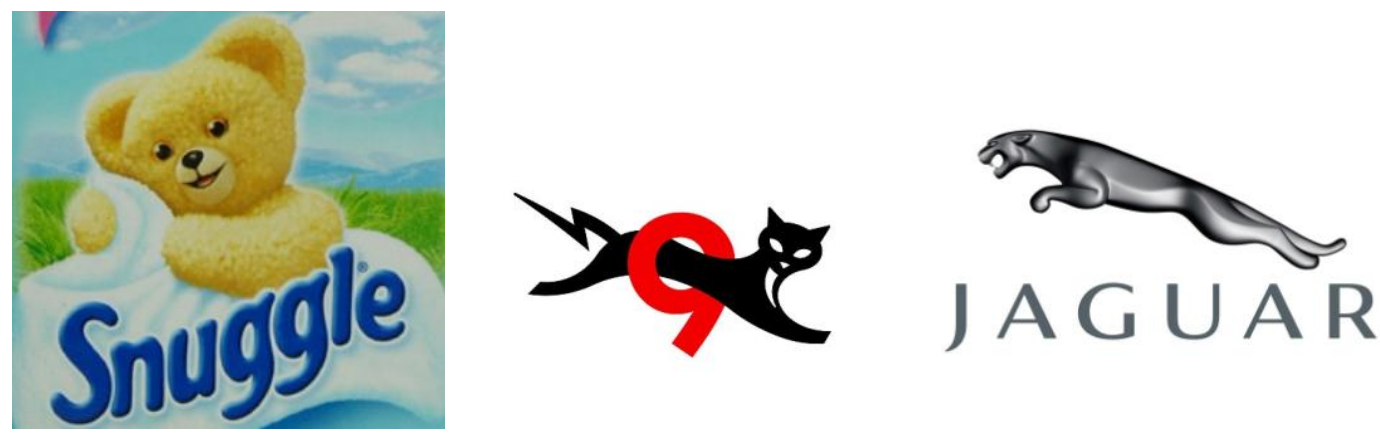

The other type of the personality symbol is magical, mythical or already known characters such as Peter Pan, Pegasus, Mr. Bean or Facit Wizard that are re-created as personality 
symbols. For example, Budweiser beer has created the Bud Man personality symbol from Superman. Campbell Soup Company has used Wizard of Oz (Dotz, 1997, p.53). This type of personality symbols can be human, animal or an abstract one. From time to time companies might also use already known characters such as Red Kit, Garfield, James Bond or Robin Hood. They might not be as magical as Pegasus but they are still already known characters. This type of personality symbols can be called" inter-textual" personality symbols. Turkcell has been one of the campanies that had prefered to used inter-textual personality symbol for launching its pre-paid phone system.

\section{Here are some examples of inter-textual personality symbols.}
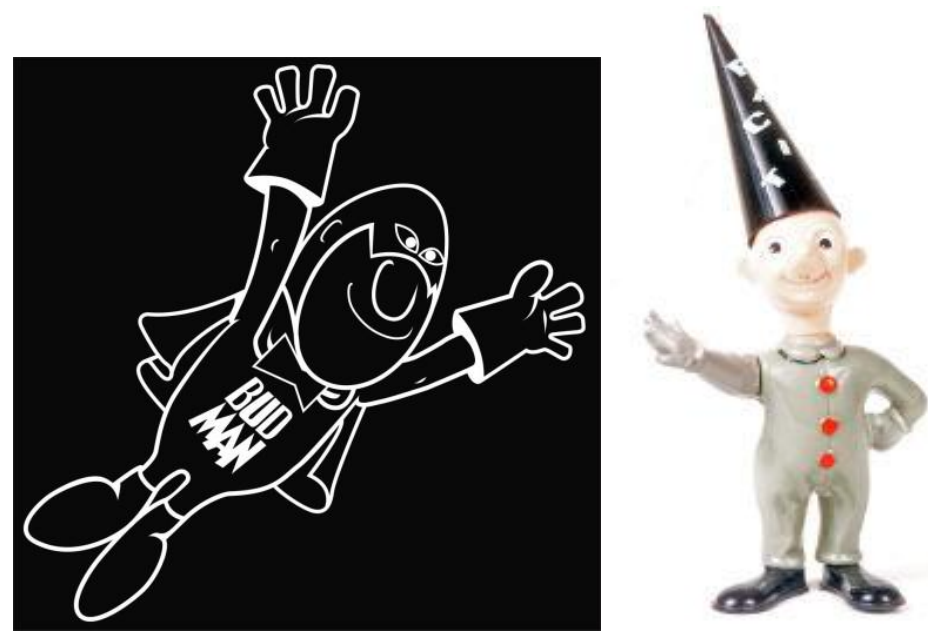

Personality symbols can also be iconic where the product or one part or the raw material of the product turns into a human figure by adding eyes, hands or legs. This type of personality symbols can also be called "literal figures". For instance, Planters Peanuts', Mr. Peanut, the Esso Oil drop for Exxon Corporation, the Michelin Man (Bibendum) for the Michelin Tire Corporation, Heinz Tomato Juice's, Aristocrat tomato or M\&M Characters (examples gathered from Dotz and Morton, 1996; Dotz, 1997). 
4. Here are some examples of iconic symbols.
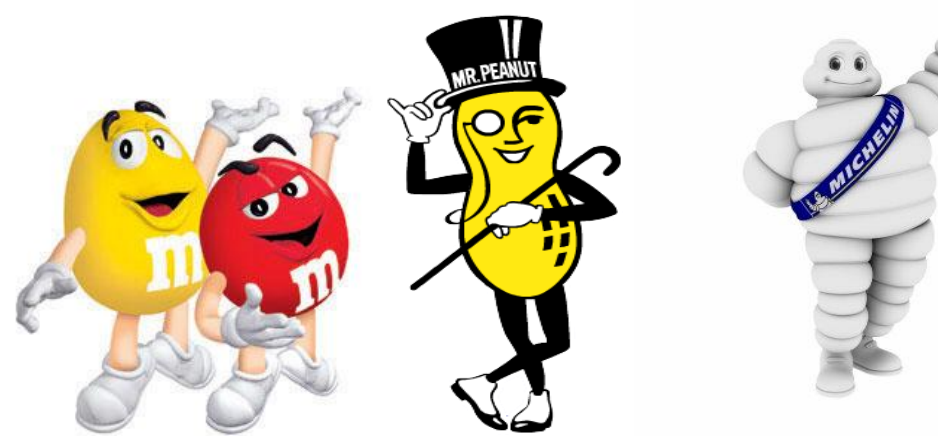

Personality symbols can be illusionary or abstract too. They can be mixture of many different objects or subjects. Like in the case of Turkish brand Turkcell. Rabbit's bottom, snail's antennas and waitress's costume has been combined to create Turkcell's personality symbol Cell-zi.. Ritalin Man and Actigall Gall Bladder have abstract shapes too. However, they all resemble human.

5. Here are some examples of illusionary/abstract personality symbols.
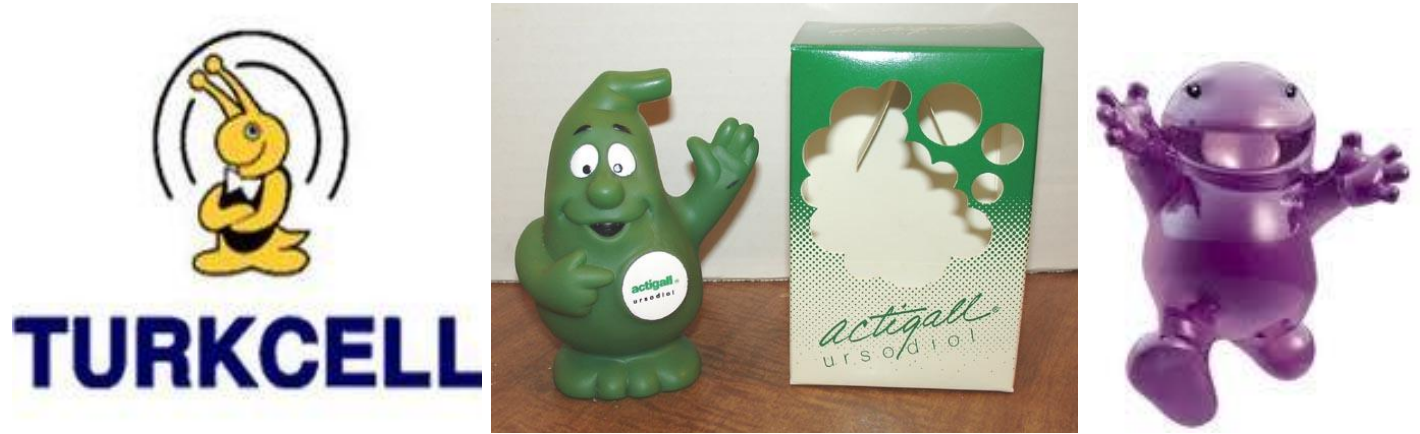

The techniques that you can apply to produce a personality symbol are endless. Stop motion, cartoon characters, animations, real faces, and so on. The creation of a personality symbol involves conceptualising. Brand's characteristics, its identity as well as the target market need to be well understood.

\section{Personality Symbol as the Company's meaning Loaded Value Guide}

Personality symbol can cover all the identifications of the brand. It can be the face or the soul of the company. They can be meaning loaded. Each symbol might hold many different values and meanings. Therefore, there always can be multiple readings of a personality symbols. Personality symbols are symbols and like any other symbols personality symbols "....represent an idea, a physical entity or a process but is distinct from it" 
(http://en.wikipedia.org/wiki/Symbol) .They “....represent something else by association, resemblance, or convention..." (http://www.thefreedictionary.com/symbol). As Berger defines, a symbol is a concrete object, a character or a letter, which stands for an intangible object or idea (1991, p.4). Like any other symbols, personality symbols are open to many interpretations which depend on culture as well as on the individual. Each audience's class, age, gender, ethnic background and education can affect his/her interpretation.

Stuart Hall suggests that "receivers can change certain meanings by their interpretations" Hall points out three positions for the reader of a text (personality symbol).

1. Dominant, a reader completely agrees with the text. (This is the kind of reading one wish to obtain for the personality symbols).

2. Negotiated reading, the reader partly shares the text's code.

3. Oppositional reader, the reader completely disagrees with the text.

Thus, the production of the personality symbol developed together with the creator (advertising agency) and the reader/target market. For a successful symbol the reading should be a dominant one.

Morley has a slightly different point from Hall. He suggests that any individual or group might operate different decoding strategies in relation to different topics and different contexts. In other words, a person might make dominant reading of the same material (personality symbol) in one context and oppositional in other context.

Morley takes the argument of dominant reading a bit further and from his arguments we can suggest that even a reader completely agrees with the suggested meaning of the personality symbol later by the effect of the other contacts he/she can start decoding the personality symbol in different ways. Therefore, how does the culture or the other receivers apart from the target audiences take part in the meaning creation of the personality symbol have essential effect on the success of the personality symbols. That is to say, others' interpretations have the potential to affect the impact of the personality symbol on the target market.

During 2001, 2002 the Turkish company Turkcell (the first GSM operator in Turkey) experienced such a case. The company started to use a personality symbol for promoting its prepaid phone system (which is called HazırKart). The personality symbol was called 'Free Girl'. She was a young, good looking woman. As the advertising agency says the feelings 
they aimed to convey by her were freedom, travelling and a sense of discovery (Halim, 2002, p.93).

'Free Girl' was travelling in the different cities of Turkey. Audiences were seeing her on the bus, on a train, climbing up to the mountains or in a boat. Wherever she goes she is able to connect and talk with her friends. Depending on the Halim's MA Thesis although $68.57 \%$ of the potential target market claimed that through her they sensed freedom, $26.05 \%$ of the surveyed found her unrealistic. They said that Free Girl does not represent Turkish culture (Halim, 2002, p. 94). What is more, on one of the national TV channels Hamdi Alkan's comedy TV program called 'Reyting Hamdi' a special episode about Free Girl was prepared where she always gets trouble while travelling. After this interpretation of Alkan's in media some writers started to suggest that a young, lonely woman travelling all through the year and every hour of the day does not suit the Turkish culture. Atıf in his articles said that the way how Free Girl presents the concept of freedom is problematic (Ali Atıf Bir, "Diziler Zorunlu Gıda Maddesi Mi / Hızır Kız!"- Are Soap operas compulsory food/ Ready Girl, Hürriyet Newspaper, 6.6.2004.Ali Atıf Bir, “Zaman: Reklamın isi eğlendirmek degil / Merve’yi kim götürüyor?" - The duty of advertising is not to entertain / who is having an affair with Merve, Hürriyet Newspaper, 29.8.2004). Ekdi (2005) also in his research says that although Free Girl has been firmly associated with Hazır Kart and freedom through the campaign, there have been different arguments about freedom, women and Turkish culture which from time to time affected the personality symbol, Free Girl in a negative way (p. 145-46).

After the rise of such interpretations Free Girl started to have a Free Boy whom was her lover and they started to search for each other. During the time, the advertising agency explained this change by saying that they wanted to make the story of the commercial more interesting and to make Free Girl more realistic. This case gives us some useful clues how the other texts or the un-targeted audiences might affect the targeted audiences' dominant readings and blur the success of the personality symbol.

Personality symbol might be a very useful communication strategy however creating a successful personality symbol is not an easy job. This research can help you in creating durable and understandable personality symbols. Above all it can guide you in creating a 
personality symbol that will provide dominant readings and will not be negatively affected by others' interpretations.

\section{The Research: Analysing the Role and the Effectiveness of Personality Symbols in Turkish TV Commercials}

The research focuses on calculating the roles and effectives of the personality symbols. It aims to bring in suggestions for developing a successful personality symbols and lists advantages and disadvantages of different types of personality symbols.

Information about the chosen personality symbols: In total 6 different personality symbols have been selected. Whereas two of them have been abounded (in 2003) other 4 are still in use. The chosen personality symbols aim to reach different target markets. They are chosen from the commercials broadcasting in the Turkish TV channels.

Lion Max is a lion personality symbol of Algida's stick ice creams. As the advertising agency points out they target children aged 6 to 12. Lion Max appears on the package, in the commercials, as a promotion tool and as a point of purchase object.

\section{Lion Max}

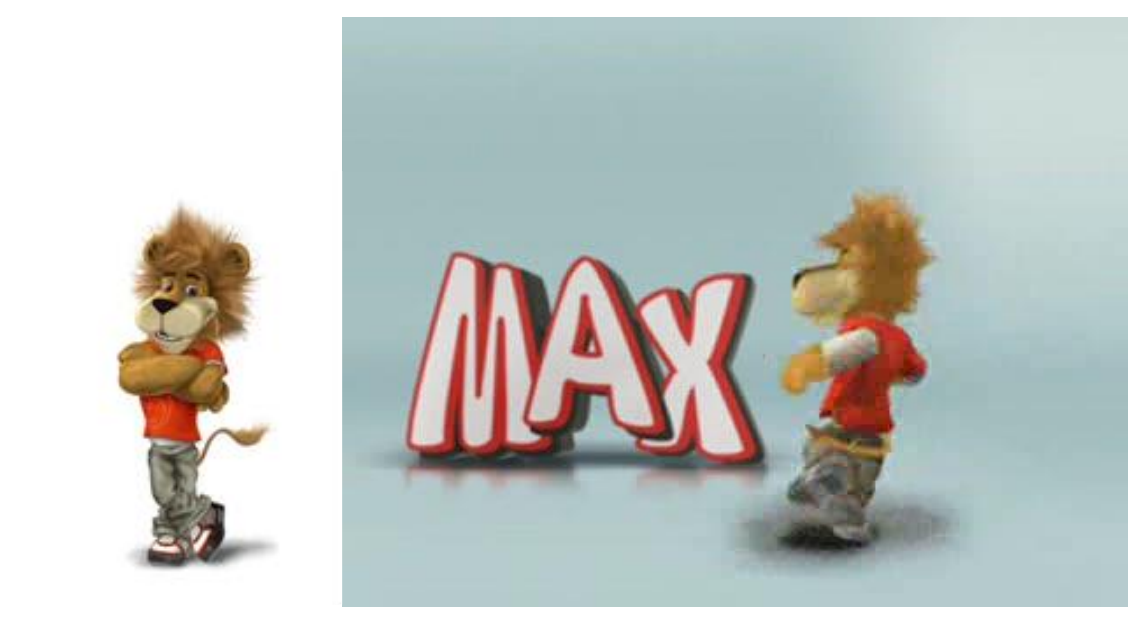

Dalin's personality symbol is another chosen symbol for the analysis. Dalin is a shampoo for babies. It is produced by Kopaş Cosmetics in İstanbul, Turkey. Its personality symbols are chicks. Dalin supports its personality symbol with a jingle. As the advertising agency states their target market consists of mothers with an average income who have children under the age of 12 . 


\section{Dalin's chicks}

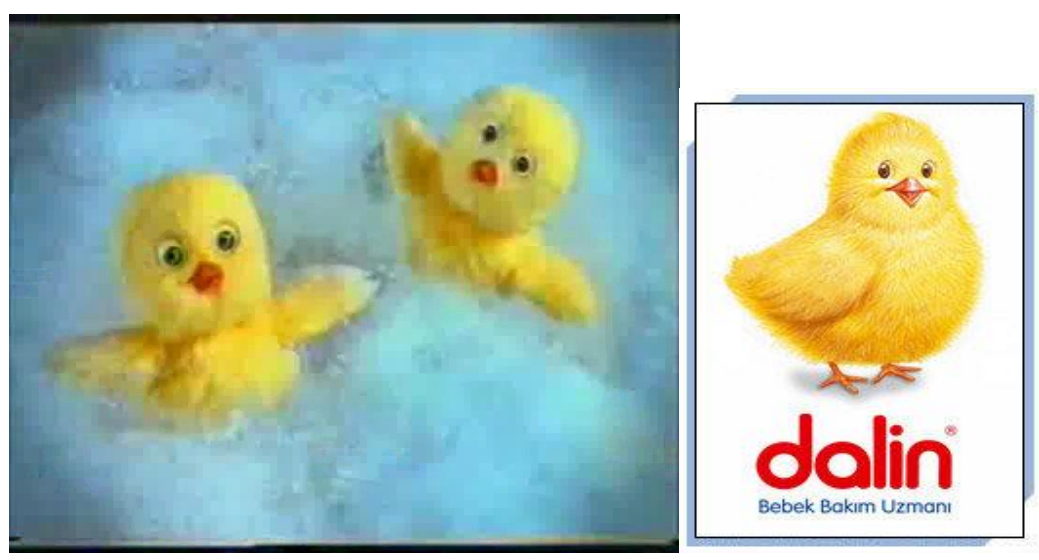

Hazır Kart is a prepaid service generating a new demand for Turkcell mobile communications and used two different personality symbols. One of them was a stick man known as Cin Ali in the Turkish culture and was an inter-textual personality symbol. The other personality symbol was a human called 'Free Girl'. Hazır Kart is for the subscribers who want to control their budgets with their calls or have more incoming than outgoing calls. Hazır Kart's main targeted market is the university students. Since 2003 the company stopped using its personality symbols.

\section{Hazır Kart's personality symbols: Stick man and Free Grill}
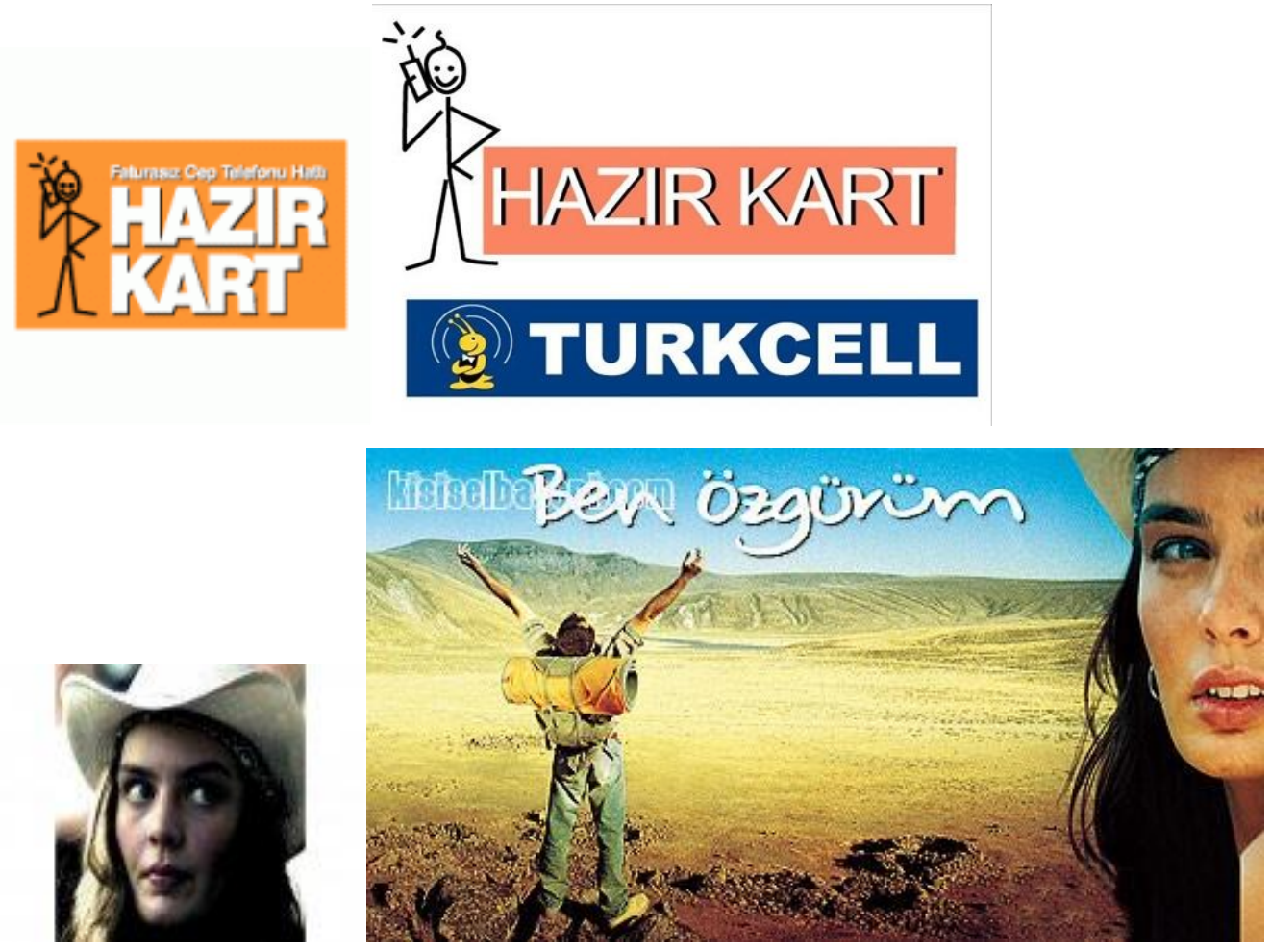
Turkcell is one of the GSM operator's that did not used personality symbols for Hazır Kart only it had always preferred to have personality symbols. It was established in 1993. Turkcell's target market has a large range. It defines its target market as the people who like to have full reception and be in the coverage area everywhere they are, at all time. "It aims to reach business people or those whose time is important". According to the research conducted by Ekdi (2005) Turkcell is declared as a prestigious brand among the others and constructs its customer profile accordingly (p.147).

Their first personality symbol was an illusionary/abstract one. He is called Cell-zi, a yellow character dressed liked a waiter with an upper part of its body like a snail and a bottom like a rabbit. According to the information gathered from the advertising agency Cell-zi is a young male who loves to learn.

\section{Cell-zi}

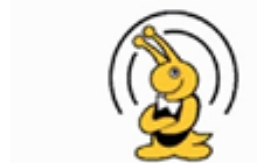

TURKCELL
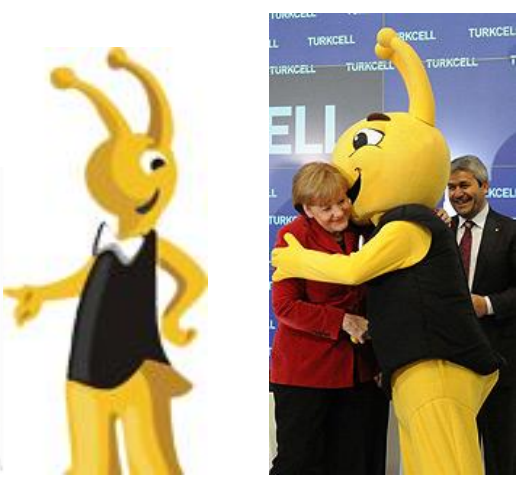

In time Cell-zi had friends and family members from different sexes and ages whom had all similar abstract appearances with snail's antennas. For him using technology is a great pleasure. Turkcell has also used many celebrities among its personality symbols. For example, Raga Oktay, Kadir Çöpdemir, Haluk Bilginer and Gürse Birsel. Turkcell's recent personality symbol is called Cello-can. The well know advertiser Serdar Erener says that while he was creating the Cello-can he preferred to touch people's heart not to their mind (Platin Magazine, 2001,http://www.reklamazzi.com/reklamcinin-gercek-odulu-yaptigi-isin-populerligidir.131171.htm) Cello-cans are different children aged around 4-6. They are dressed up like Cell-zi. They have a hat which has yellow antennas just like the Cell-zi. 


\section{Cell-zi's family}
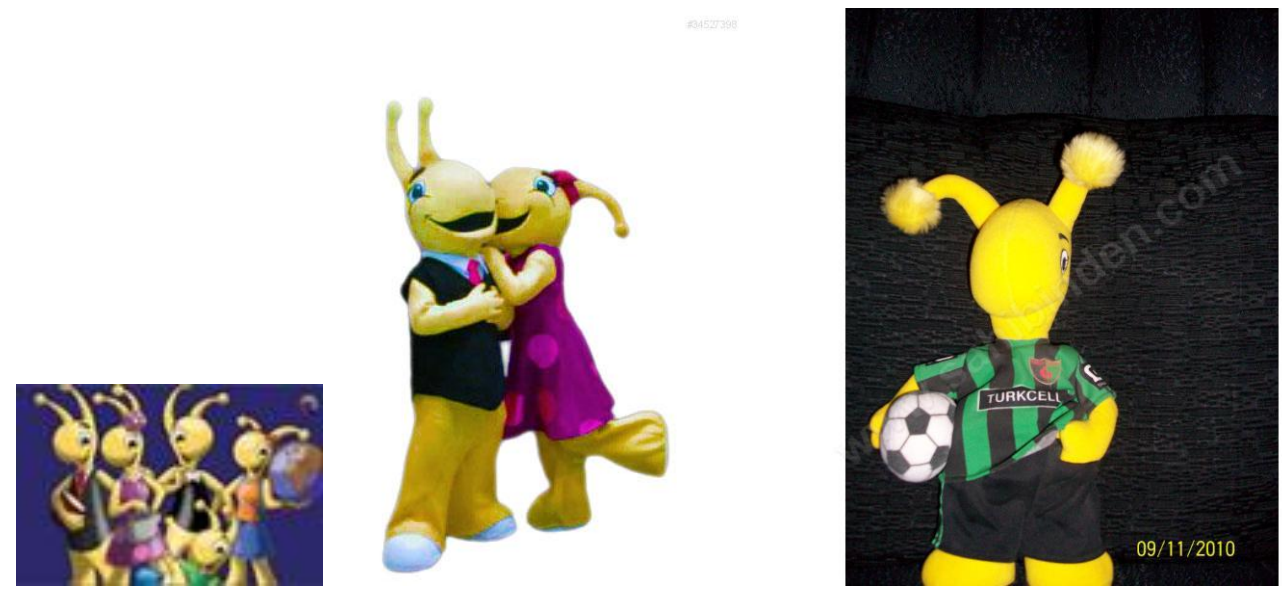

\section{Turkcell's latest personality symbol Cello-cans}

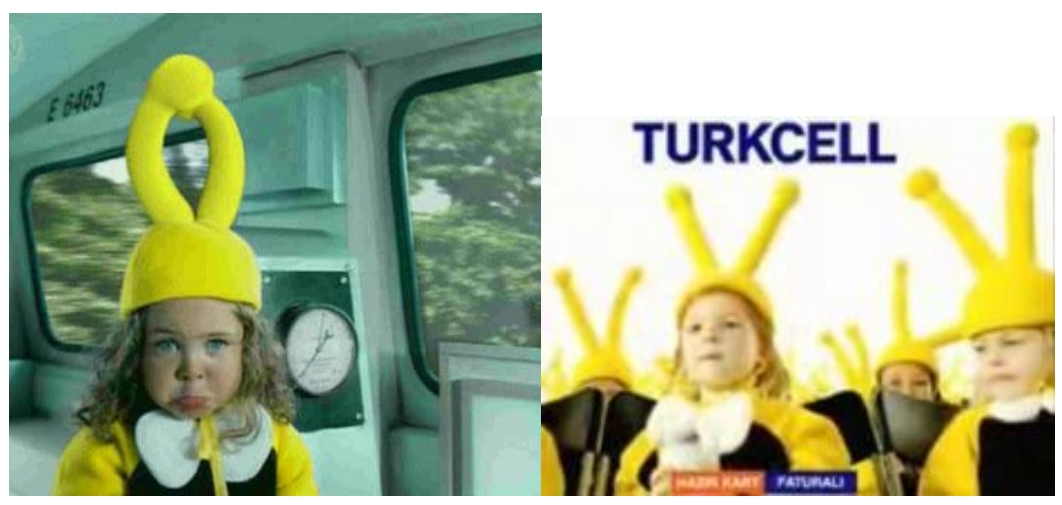

Methodology of the research: The research has three parts. The first part covers the information collected by the related advertising agencies. By using scheduled interviews with the advertising agencies, personality symbols were thoroughly analysed from their colours to their surroundings. Advertising agencies creative and strategic directors were asked what kind of associations or attachments they have aimed to create. Along with the information given by the agencies, data from secondary sources such as advertising magazines and previously done researches have been used to have a better understanding of the personality symbols.

Then, in depth interviews have been conducted with the selected 10 audiences who possessed the main characteristics of the target market of the chosen personality symbols. The main aim was to do a deeper analysis of the perceptions of the personality symbols. In addition to these 
10 in depth interviews focus groups have been formed. For forming the groups and analysing them Morgan's (1998) suggestions have been followed. During the research not only what people think but how they think and why they think that way about the personality symbols has been examined.

The final part of the research compares the outcomes of the information obtained from the interviews had with the advertising agencies and the information received from the related personality symbol's target market audiences.

Data Gathering: The research is based on secondary and primary data. Secondary data's are collected from previously published articles, researches and chosen brands' announcements. For two of the personality symbols -Free Girl and Cin Ali- which are not in use today the outcomes of the two previously done MA researches' have been used.

The primary data for every personality symbol was collected from the relevant advertising agencies. The advertising agency Y \& R Reklamevi Reklamcılık A.Ş. provided information about the Hazır Kart's and the Turkcell's personality symbols. Mr.Deniz of San Graphic in İstanbul who is the main creator of Cell zi also provided some vital information regarding Turkcell's personality symbol. Dalin's (baby shampoo) personality symbols' information was also collected from the same advertising agency. For Algida's Lion Max personality symbol the information collected from the Ogilvy \&Mather Reklamcılık A.Ş.

Apart from 10 audiences with whom in depth interviews have been conducted 76 people have also joined to the focused groups. For Hazir Kart's and Turkcell's first personality symbols İpek Halim's (2002) and Barış Ekdi's (2005) MA Thesis has been used. For Turkcell's latest personality symbol three focus groups have been organized with 24 participants. For Dalin two focus groups have been conducted with twenty three (23) participants. For Max three focus groups realised with thirty (30) informants.

All the focus group participants have asked to watch a recorded commercial break where the researched commercials have been inserted in. After having watched the commercials they were asked to indicate the commercials they remember and enjoy watching. After learning if they like and remember the commercials with personality symbols or not then they have been asked to only watch the commercial with the personality symbol and reflect their ideas, feelings about the personality symbols. 
Sample of the research: Different personality symbols are chosen. They have different technical executions, different types and aim to reach to different target markets. For example; Lion Max is a cartoon animal personality symbol which aims to reach children. Cin Ali is a two dimensional drawing (stick man). It is an inter-textual personality symbol that aims to communicate with young people and to convince them that the pre-paid phone system is easy to use.

Free Girl is a human personality symbol-young woman- which aims to reach mostly young people. The chicks of Dalin baby shampoo are three dimensional stop motion model animals which aim to reach mothers with average income. Cell zi is a unique, abstract, illusionary personality symbol. Cell zi has a wide target market, from young to elderly people. Cello-can is a human personality symbol - children- which derived from Cell-zi.

Limitations of the Study: This research only aims to analyse the process of communication between personality symbols and the defined target market. The research does not aim to analyse the interrelations with the personality symbols and the every viewer. The findings of this research are not intended to give implications on complete advertising strategies of the brands. For example, the research does not question if the target markets are chosen correctly or the timing or the frequency of appearance of the commercials. Also, it should be kept in mind that the samples have been chosen from the Turkish media and might have some different interpretations in different cultures.

\section{Findings: The Effectiveness of the Personality Symbols}

Commercials with personality symbols take the attention of their target market. The majority of the participants have said that such commercials are on their favourite commercial lists. Thus, the related target market is not only aware of such commercials but also enjoy watching them. After finding out that in general the personality symbols are found interesting they have been asked to analyse each and every one in details.

Free Girl: Participants indicated that they associated Free Girl with freedom and discovery. These were the intended feeling which the advertising agency aimed to transfer to the target market. The same majority of the participants pointed out that they enjoyed watching Free Girl as the music and the story of the commercial was appealing and exciting. A few of the participants stressed that Free Girl is not a realistic character and does not fit into the Turkish 
traditions. Although the ones who bring into such claims were little in numbers they were very aloud and rigid in their ideas (Halim, 2002, pp93-94).

Cin Ali: According to Halim's (2002) research to the question "what does Cin Ali mean in Hazır Kart commercials" $84.44 \%$ of the informants claimed that Cin Ali reminds them of their childhood or the elementary school. He is funny, young, dynamic and simple. Such explanations had matched with the advertising agencies reason for choosing Cin Ali as their personality symbol (2002, pp92-93). The agency suggests that just in the way when Cin Ali in our elementary schools taught us how to read and write he will now teach us how to use prepaid phones. Everything is simple in our old friend's world. If he uses this system this means that everyone can do so, too. It is also important to have a look at the other $15 \%$ participants' interpretations. Whereas some of them have said that Cin Ali reminds them their stressful school life some others said that they find Cin Ali unserious and week.

Turkcell's first -abstract- personality symbol Cell-zi mostly defined as sympathetic and reliable. Its antennas have been found as very attention drawing. On the other hand, very few of the participants were able to defined Cell-zi as a combination of a snail and a rabbit. Mostly the informants said that they cannot understand what he is. One participant said that it's an ant and two of the other participant defined Cell zi as a bee.

The middle aged and the business running participants found Cell-zi childish. They said that they cannot take Cell-zi as serious. It was said that, he is not suitable for Turkcell as it is a cartoon character. Although in general Cell-zi's antennas draw people's attention and it is associated with good coverage area it also provides some unintended and unwanted readings as well. The participants also said that it has a very eye catching, vivid colour. About his black jacket and the bow-tie it has been said that it gives him a cute, kind and a respectful look.

Cello-can: Cello-cans' catch attention of the participants too. Mostly they are defined as cute. Two of the female participants defined them as angles. "They are angles helping people to solve their communication problems". In general they have been described as honest, cute, with full of energy and good hearted. Men also said that they like to watch these kids in such costumes running around. Their energy and positive modes affects them, too. 
On the other hand, one participant in both focus groups have opened a critical conversation on how 'right' is it to use children on the commercials. This discussion also takes place on the social media in Turkey. Turkcell has just -in June 2011- ended a competition where they asked the public to offer and to select the children whom they like to be the next Cello-can. Medias like Uludağ dictionary has suggested that Cello-cans are unethical and they are abusing the families as well as the children and the audiences (www.uludagsozluk.com/k/cellocan/).

Ocakoğlu (2006) has also given space to Cello-can in her article and suggested that children are affected from this character. She says that there are many kids who are willing to dress up like cello-can. She also suggests for further researches to analyze how such commercials might affect the children and also argued that law should be clearer and must always be protective of the child (http://www.turkcebilgi.com/kose_yazisi_90846_gunseli-ozenocakoglu-cocuklarin-reklamlarda-rol-almasi-sakincali-mi.html). Such discussions might of course affect the success of the personality symbol in a negative way.

Dalin's chicks: Apart from two mothers all the mother participants said that chicks of Dalin remind them of purity, softness and sensitivity. They liked Dalin's chicks, their dances in the bath and every mother has learnt the song they sing by heart. It was interesting to see that they were all singing the song as the chicks were doing. The mothers said that the way the chicks sing is one of the reasons why they like them and think that they are cute. A few of the mothers had also said that the chicks are like their children. Apart from all these matching, positive claims one mother said that Dalin's chicks remind her of another commercial. In the focus groups of Dalin all the mothers said that they like and enjoy watching Dalin's commercials.

Max: In the focus groups of the Algida's Max ice cream all of the children said that they like Lion Max. There was no difference among the girl and the boy respondents. They defined Max as powerful, active, and strong. They also said that they want to be like him. Three of the participant children said that they prefer him-Max- to be their friend. While, most of the children focused on the personality symbol, a few of the children mentioned the surroundings of Max as well. They mentioned about the clouds, temple and the monsters. Just one child, who is 6 years old, said that she does not like the monsters. As she is afraid of them. 


\section{Summary of the results}

Personality symbols do take attention and it is easy to remember them. In the light of all the information gathered from previously conducted surveys and the in depth interviews, it can be suggest that in the case of abstract/illusionary personality symbols like Cell-zi which is the combination of the two different animals, present problems of identification by its target market and when it becomes difficult to tell what it is it might lead to some unwanted multiple readings. On the other hand, the attached associations to the Cell-zi have also been understood as it is intended. Cell-zi has been a widely discussed personality symbol. While some of its target market liked and interpreted it in the way as the agency intended to some others strongly found it inappropriate for the brand and had association problems. The reason for such misinterpretations and different readings is mostly caused by the wideness of its target markets. That was the reason why the advertising agency created Cell-zi's family. Cell-Jr who enjoys football, Cellita who loves shopping and Cell-dede who was in his 70's but still feels young.

Through the Cell family the company aimed to be able to reach different segments however the participants of the focus group clearly expressed that they do not feel close to the Cell-zi family too. Whereas some of the participants said that they do not like Cell-zi some others claimed that by adding the family members to the commercial it became more childish and boring.

This leads us to think that cartoon, unreal personality symbols can be attention drawing but can also make the possibility childish and despise. When Cell-zi converted into a human/child its interpretations started to be better. Cello Cans are defined and appreciated more than the Cell-zi however using a human easily provokes cultural discussions especially when it is a child.

Free Girl like Cello Cans and some other human personality symbols provoked cultural discussions, too. Not only in Turkey but also in different cultures we come across with such problems in the usage of a human personality symbol. For example, Aunt Jemima who is a human personality symbol was under criticism that her image of a black mammy in a kerchief was supporting the gender and ethnic inequality. Human personality symbols might also easily be out-dated very easily. For example a well- known human personality symbol Betty 
Crooker's dressing, hairstyle, make up and even age and skin colour has changed more than five times since it is introduced (Batra, R. Myers, J. G. Aaker D, A, 1996, pp. 323-324).

Along the way another well- known human personality symbol the image of the Kentucky Fried Chicken have been changed to reflect the changing culture. The old man with glasses started to shoot hoops and dance. KFC ad Chief Terry Davenport says that by changing their personality symbols appearance and especially updating its attitudes the sales consistently increased. (USA today ad track http://www.usatoday.com/money/index/ad246.htm).

\section{Up dated human personality symbol: Betty Crooker}
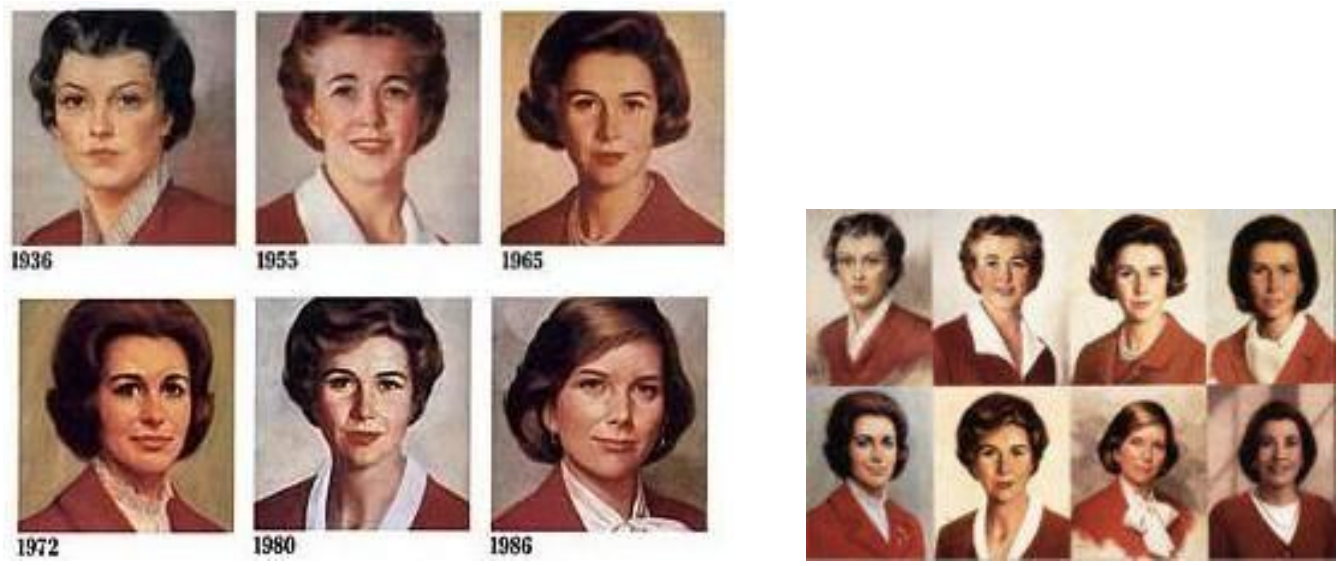

Like humans, animals are very widely used as personality symbols. In Dalin's case its personality symbol is chicks and they are able to take attention and it is interpreted as it is intended to by its target market. The success of this personality symbol lies on being able to create a good connection between the chicks and the children. The song of the commercial enhanced its appeal, too. Plus, its well defined and relatively narrow target market paid an important role in the success of the personality symbol.

The participants' claims also highlight that the environment as well as the music, song or the jingle has a great role in increasing the effectiveness of the personality symbols. Such as Dalin's, Max's and Free Girl's success enhanced by their jingles and music. It helps the target market to read the intended message in the way initially desired. In general the supporting elements of the personality symbol such as music, images, colours, and environment affect the success of the personality symbols. On the other hand, the continuing story telling in the commercials as in the case of the Free Girl might draw the attention away from reading the personality symbol and the audiences might focus more on the story itself. 
The outcomes can also be itemised into three groups.

1: Listing the possible advantages of using a personality symbol.

2: Listing the possible disadvantages of the personality symbols and

3: Highlighting some significant elements that might assist one to develop successful personality symbols.

1. Group, The advantages of using a personality symbol in commercials

- They attract attention

- They are mostly remembered

- Generally understood as intended

- Just showing a part of a strong personality symbol can remind of the full personality symbol and sustain the same effect of the complete personality symbol. This characteristic allows the creator to be more creative and gives them a freedom to play/change the personality symbol.

- Inter-textual personality symbols can be accepted easily and the attributions that are already attached to it can help the personality symbol to be understood in a shorter time with fewer misinterpretations.

- Using children as personality symbols can create strong emotional effects on the target market.

2. Group, The disadvantages of using personality symbols in commercials

- They might not be completely understood as intended.

- Cartoon and puppet personality symbols might be seen childish by adult target market.

- To understand what the abstract personality symbol might be complicated and difficult.

- Human personality symbols can easily provoke cultural discussions. Non target media can re-produce the meaning of the personality symbol and can add some unplanned attributions to it. Therefore, the perception of the target market can be open to many different influences.

- Inter-textual personality symbols may bring up its previous attribution and can loosen the connection with the brand. It might remind the older/original text. 
- It becomes difficult to reach to a wide target market with a single personality symbol.

3. Group, The items that can improve the success of the personality symbols can be suggested as;

- Personality symbol's environments help them to be understood better.

- Music, jingles, behaviours, voice and dressing styles are all factors which influences the effects of the personality symbols.

- Not only the type of the personality symbol should be appropriate to the brand and the target market but also its execution style should be selected accordingly.

- For developing an effective personality symbol target market must be well defined and studied.

- Although one of the strengths of the personality symbols is their durability in time they should have slight changes in order to be updated.

- The stories of the commercials can support the success of the personality symbols.

- Attention drawing personality symbols are those which are cute and able to touch the target market's heart.

- Funny and agile personality symbols grab attention.

- Animal and cartoon personality symbols can have more impact on the children or on the children's products.

- The personality symbol should be relevant to the brand and the target market.

- Simplicity might be helpful. Some characters work best with simple missions.

\section{Conclusion}

The study examines many different personality symbols. It aims to categorise them and measure how accurately they are read by their target audiences. In other words, it discusses their success and weaknesses. It suggests that although personality symbols can be durable, easy to memorise, attention taking and adaptable to different Medias, platforms and surfaces they can be misinterpreted as well. They are like any other symbol. Can be meaning loaded, complex and can cause multiple readings. 


\section{References}

Belch, G. E. and Belch, M.A. (1999). Advertising and Promotion. McGraw-Hill, International edition.

Bir, A. A.( 2005). Diziler Zorunlu Gıda Maddesi Mi / Hızır Kız!, Hürriyet Gazetesi

Bir, A. A. (25.2.2001). Bypass'ın Sonuçları Üzerine/ GSM'ler Arası Savaş Nefes Kesiyor, Hürriyet Gazetesi,

Bir, A, A. (5.2.2002). Turkcell bir Cell-o-Budsman Yaratıyor, Hürriyet Gazetesi,

Bir, A. A. (9.11.2003) Tekel'e Fazla Bile Verdiler / Kadir'in Fendi Selo'yu Yendi, Hürriyet

Gazetesi.

Chandler, D. (2002). Semiotics: The Basics. Routledge: London

Dotz, W. and Morton, J. (1996). What a Character, World Studio: , Hong Kong

Dotz, W. (1997). Advertising Character, Image graphics Inc: Paducah.

Ekdi, B. (2005). Marka İmajı Yaratma ve Yerleştirme. (MA Thesis). T.C. Ankara Üniversitesi.

Gwinner, K. P. and Eaton, J. (1999). Building Brand Image Through Event Sponsorship: The Role of Image Transfer. Journal of Advertising, Vol. XXVII, No:4, .47-57.

Halim, I. (2002). The Analysis of the Role and Effectiveness of Personality Symbols in TV Commercials. (MA Thesis) Eastern Mediterranean University.

Marra, J. I. (1990). Advertising Creativity, Prentice -Hall: USA.

Ocakoğlu, Ö. (16 July 2006, Sunday) Çocukların reklamlarda rol alması sakıncalı mı? (http://www.turkcebilgi.com/kose_yazisi_90846_gunseli-ozen-ocakoglu-cocuklarinreklamlarda-rol-almasi-sakincali-mi.html)

Serdar, E. (2001). Reklamcının Gerçek Ödülü Yaptığı İşin Popülerliğidir. http://www.reklamazzi.com/reklamcinin-gercek-odulu-yaptigi-isinpopulerligidir.131171.htm). Platin Magazine.

Schultz, D. P. and Schultz S. E. (1998). Psychology and Work Today. Prentice-Hall Inc. New Jersey.

Uludağ Sözlük (www.uludagsozluk.com/k/cellocan/).

The Free Dictionary. http://www.thefreedictionary.com/symbol.

Wikipedia Free Encyclopedia: http://en.wikipedia.org/wiki/Symbol.

Zeren, A, (2009, September). Reklamlarda İkon Kullanımı Pazarilla, 23:47. 